University of Nebraska - Lincoln

DigitalCommons@University of Nebraska - Lincoln

Publications from USDA-ARS / UNL Faculty

U.S. Department of Agriculture: Agricultural

Research Service, Lincoln, Nebraska

2003

\title{
Identification of Assemblage A Giardia in White-Tailed Deer
}

J. M. Trout

United States Department of Agriculture

M. Santin

United States Department of Agriculture, monica.santin-duran@ars.usda.gov

R. Fayer

United States Department of Agriculture, ronald.fayer@ars.usda.gov

Follow this and additional works at: https://digitalcommons.unl.edu/usdaarsfacpub

Part of the Agricultural Science Commons

Trout, J. M.; Santin, M.; and Fayer, R., "Identification of Assemblage A Giardia in White-Tailed Deer" (2003). Publications from USDA-ARS / UNL Faculty. 457.

https://digitalcommons.unl.edu/usdaarsfacpub/457

This Article is brought to you for free and open access by the U.S. Department of Agriculture: Agricultural Research Service, Lincoln, Nebraska at DigitalCommons@University of Nebraska - Lincoln. It has been accepted for inclusion in Publications from USDA-ARS / UNL Faculty by an authorized administrator of DigitalCommons@University of Nebraska - Lincoln. 
This article is a U.S. government work, and is not subject to copyright in the United States.

\title{
Identification of Assemblage A Giardia in White-Tailed Deer
}

\author{
J. M. Trout, M. Santin, and R. Fayer, Environmental Microbial Safety Laboratory, Animal and Natural Resources Institute, Agricultural \\ Research Service, United States Department of Agriculture, Beltsville, Maryland 20705. e-mail: jtrout@anri.barc.usda.gov
}

ABSTRACT: Fecal samples were collected from hunter-killed whitetailed deer (Odocoileus virginianus) during a managed hunt in a central Maryland county. Fecal samples were cleaned of debris and concentrated by $\mathrm{CsCl}$ density gradient centrifugation and stained with MerIFluor rix reagents. Stained samples were examined by fluorescent microscopy for the presence of Giardia sp. cysts. One of 26 samples was found to be positive for Giardia sp. Polymerase chain reaction amplification using primers directed to the $\beta$-giardin and TPI genes identified the same sample as the only positive one. Sequencing of the $\beta$-giardin and TPI genes revealed that the Giardia sp. belonged to assemblage A, a genotype infectious for humans and also reported in a small percentage of cattle. This is the first report of assemblage A Giardia sp. in deer and suggests that deer could be a potential source of infectious cysts for humans and cattle.

Giardia spp. are well-recognized intestinal parasites of animals and humans, capable of causing a variety of symptoms including diarrhea and malabsorption of nutrients. Giardia duodenalis (syn. intestinalis, lamblia) infects a wide range of mammalian hosts, but recently molecular analysis has allowed the subtyping of this group into a number of genotypes. Typically, only genotypes in assemblages A and B are found in human infections (Thompson et al., 2000). Giardia sp. has been reported in elk (Elaphus nonnodes) (Deng and Cliver, 1999; Heitman et al., 2002), roe deer (Capreolus capreolus) (Pavlasek et al., 1993), free-ranging white-tailed deer (Odocoileus virginianus) (Rickard et al., 1999), and moose (Alces alces) (Heitman et al., 2002). However, these studies did not indicate the Giardia sp. genotype, thus it was not clear whether Giardia sp. of cervid origin had the potential to infect humans. The present study was conducted to examine the genotypes of Giardia sp. present in free-ranging white-tailed deer.

Deer feces were collected from hunter-killed animals during a managed deer hunt in central Maryland. The hunt was conducted under the supervision of county officials as part of a wildlife management program. Age and sex data were recorded for each animal sampled. Fifteen grams of feces were weighed and placed in a 50-ml tube, and water was added to bring the total volume to $50 \mathrm{ml}$. Feces and water were mixed well, and the suspension was passed through a $45-\mu \mathrm{m}$ screen. The screened material was centrifuged at $1,500 \mathrm{~g}$ for $10 \mathrm{~min}$. The supernatant was discarded and the pellets resuspended in $25 \mathrm{ml}$ of $\mathrm{dH}_{2} \mathrm{O}$. Twenty-five $\mathrm{ml}$ of $\mathrm{CsCl}$ (density $=1.4 \mathrm{~g} / \mathrm{L}$ ) was added to each sample and mixed well, and the tubes were centrifuged for $20 \mathrm{~min}$ at $500 \mathrm{~g}$. After centrifugation, the top $4 \mathrm{ml}$ of the solution was removed from each tube and placed in 15-ml tubes. Eleven $\mathrm{ml}$ of $\mathrm{dH}_{2} \mathrm{O}$ was added and mixed well, and the tubes were centrifuged at 1,500 $\mathrm{g}$ for $10 \mathrm{~min}$. 
The supernatant was discarded, and the pellets were resuspended in 500 $\mu \mathrm{l}$ of $\mathrm{dH}_{2} \mathrm{O}$; of this volume, $100 \mu \mathrm{l}$ was used for immunofluorescent analysis (IFA) analysis and $50 \mu 1$ for DNA analysis. The remainder was frozen as an archival sample. For IFA analysis, the $100 \mu 1$ was placed in a microcentrifuge tube and centrifuged at $3,000 \mathrm{~g}$ for $5 \mathrm{~min}$. The pellet was resuspended in $25 \mu \mathrm{l}$ of $\mathrm{dH}_{2} \mathrm{O}$, to which was added $25 \mu \mathrm{l}$ of MerIFluor reagent (Meridian Biosciences, Inc., Cincinnati, Ohio). Two microliters of this mixture was pipetted into an 11-mm-diameter well of a heavy-Teflon ${ }^{\circledR}$-coated 3-well slide (Cel-Line, Erie Scientific, Portsmouth, New Hampshire). Coverslips were placed on slides, and samples were examined for the presence of Giardia sp. cysts using a Zeiss Axioskop equipped with epifluorescence and a Texas Red-fluorescein isothiocyanate dual wavelength filter.

Total DNA was extracted from $50 \mu \mathrm{l}$ of the processed feces using a QIAampTissue Kit (Qiagen, Valencia, California) with a slightly modified protocol. The protocol, described below, used reagents provided by the manufacturer. The $50 \mu \mathrm{l}$ of processed feces was resuspended in $180 \mu \mathrm{l}$ of ATL buffer thoroughly mixed by vortexing. To this suspension, $20 \mu \mathrm{l}$ of Proteinase K $(20 \mathrm{mg} / \mathrm{ml})$ was added, and the sample was mixed by vortexing. After incubating the mixture overnight at $55 \mathrm{C}$, $200 \mu \mathrm{l}$ of AL buffer was added. The remaining protocol followed the manufacturer's instructions, with 1 exception. To increase the quantity of recovered DNA, the nucleic acid was eluted in $100 \mu \mathrm{l}$ of AE buffer.

A 753-bp fragment of the $\beta$-giardin gene was amplified using the forward primer G7 (5' AAGCCCGACGACCTCACCCGCAGTGC 3') and the reverse primer G759 (5' GAGGCCGCCCTGGATCTTCGAGACGAC 3') (Cacciò et al., 2002).

A 500-bp fragment of the TPI gene was amplified using nested polymerase chain reaction (PCR) for the primary amplification primers AL3543 (5' AAATIATGCCTGCTCGTCG 3') and AL3546 (5' CAAACCTTITCCGCAAACC $3^{\prime}$ ) and the secondary amplification primers AL3544 (5' CCCTTCATCGGIGGTAACTT $3^{\prime}$ ) and AL3545 (5' GTGGCCACCACICCCGTGCC 3') (Sulaiman et al., 2003).

Amplification was conducted using a 50- $\mu 1$ suspension of the following reagents: $10 \mathrm{mM}$ Tris- $\mathrm{HCl}(\mathrm{pH} 9), 50 \mathrm{mM} \mathrm{KCl}, 1.5 \mathrm{mM} \mathrm{MgCl} 2$, $0.2 \mathrm{mg} / \mathrm{ml}$ bovine serum albumin, $0.5-1 \mu \mathrm{M}$ of each primer, $0.2 \mathrm{mM}$ of each deoxynucleotide triphosphate, and $2.5 \mathrm{U}$ of Taq DNA polymerase (Qbiogene Inc., Carlsbad, California). PCR was carried out on a PTC-200 thermocycler (Peltier Thermal Cycler, M. J. Research, Reno, Nevada). To amplify the TPI gene, samples were heated to $94 \mathrm{C}$ for 3 min, followed by 35 cycles of $94 \mathrm{C}$ for $45 \mathrm{sec}, 50 \mathrm{C}$ for $45 \mathrm{sec}$, and $72 \mathrm{C}$ for $1 \mathrm{~min}$, and a final extension at $72 \mathrm{C}$ for $3 \mathrm{~min}$. To amplify the $\beta$-giardin gene, samples were heated to $94 \mathrm{C}$ for $5 \mathrm{~min}$, followed by 40 cycles of $94 \mathrm{C}$ for $30 \mathrm{sec}, 65 \mathrm{C}$ for $30 \mathrm{sec}$, and $72 \mathrm{C}$ for $1 \mathrm{~min}$, and a final extension at $72 \mathrm{C}$ for $7 \mathrm{~min}$. A negative control consisting of a reaction mixture without the DNA template was included in each experiment. As a positive control, G. duodenalis DNA was extracted from samples (positive by microscopy and PCR) collected from cattle. PCR products were analyzed on $1 \%$ agarose gel and observed by ethidium bromide staining.

PCR products were purified using EXO-SAP enzyme (USB Corporation, Cleveland, Ohio) and sequenced (G7-G759 primers for $\beta$-giardin and AL3544-AL3545 primers for TPI) in 10- $\mu$ l reactions using Big Dye ${ }^{\text {(ix) }}$ Chemistries and an ABI3100 sequencer analyzer (Applied Biosystems, Foster City, California). Each sample was sequenced in both directions. Sequence chromatograms from each strand were aligned and inspected using Lasergene software (DNASTAR, Inc., Madison, Wiscon$\sin )$.

Giardia sp. cysts were detected by IFA only in 1 of 26 samples (a female, approximately 6 mo of age), for an overall prevalence of $3.8 \%$. Similar prevalence has been found in white-tailed deer in Virginia $(1.1 \%)$ (Rickard et al., 1999) and Mississippi (2.9\%) (Rickard et al., 1999) and in elk (3.7\%) in California (Deng and Cliver, 1999), whereas in western Canada, a very low percentage of deer were positive $(0.15 \%)$ (Heitman et al., 2002). Ranched elk in western Canada exhibited a higher percentage of Giardia (15.8\%), whereas free-ranging elk were negative (Heitman et al., 2002); less than $1 \%$ of moose tested in western Canada were Giardia-positive (Heitman et al., 2002). The low prevalence reported might be a reflection of intermittent shedding of Giardia sp. cysts or the age of the animals studied. Prevalence may also be underestimated because we have only a single sample per animal.

PCR amplification and gene sequencing confirmed the detection and identification of Giardia sp. by IFA. The sequences coding TPI and $\beta$ - giardin genes have been submitted to GenBank under the accession numbers AY302562 and AY302561 for TPI and $\beta$-giardin genes, respectively.

The TPI- and $\beta$-giardin-coding sequences of this Giardia isolate were compared with other TPI and $\beta$-giardin gene sequences from GenBank. Our TPI gene sequence showed a $99.8 \%$ similarity to $G$. duodenalis assemblage A, group I, AD-1 strain (AF069556, Monis et al., 1999), which was originally isolated from a human duodenal aspirate and characterized by Andrews et al. (1989). The $\beta$-giardin gene sequence showed $98.1 \%$ similarity to assemblage A (AY072724), reported by Cacciò et al. (2002).

This is the first report of assemblage A, group I G. duodenalis in deer and suggests that deer could be a potential source of infectious cysts for humans or other animals. Assemblage A Giardia sp. has recently been reported in a small percentage of calves (O'Handley et al., 2000; van Keulan et al., 2002), raising the possibility that cattle and deer, which often share pasture land, each have the potential to pass infections to the other. Although the white-tailed deer population in the United States is estimated to be in the tens of millions, data on the prevalence and genotypes of Giardia sp. isolated from naturally infected deer remain limited. Further studies, perhaps focusing on younger animals, which may be more likely to be infected, are needed because deer represent a potentially significant reservoir of infection within the environment.

The authors wish to thank Kristie Ludwig for her expert technical assistance and Phil Norman for coordinating the sample collections.

\section{LITERATURE CITED}

Andrews, R. H., M. Adams, P. F. L. Boreham, G. Mayrhofer, AND B. P. Meloni. 1989. Giardia intestinalis: Electrophoretic evidence for a species complex. International Journal for Parasitology 19: 183190.

CACCiò, S. M., M. DE Giacomo, ANd E. Pozio. 2002. Sequence analysis of the $\beta$-giardin gene and development of a polymerase chain reaction-restriction fragment length polymorphism assay to genetype Giardia duodenalis cyst from human faecal samples. International Journal for Parasitology 32: 1023-1030.

DENG, M. Q., AND D. O. CLIVER. 1999. Improved immunofluorescence assay for detection of Giardia and Cryptosporidium from asymptomatic adult cervine animals. Parasitology Research 85: 733-736.

Heitman, T. L., L. M. Frederick, J. R. Viste, N. J. Guselle, U. M. Morgan, R. C. A. Thompson, And M. E. Olson. 2002. Prevalence of Giardia and Cryptosporidium and characterization of Cryptosporidium spp. isolated from wildlife, human, and agricultural sources in the North Saskatchewan River Basin in Alberta, Canada. Canadian Journal of Microbiology 48: 530-541.

Monis, P. T., R. H. Andrews, G. Mayrhofer, and P. L. Ey. 1999. Molecular systematics of the parasitic protozoan Giardia intestinalis. Molecular Biology and Evolution 16: 1135-1144.

O’Handley, R. M., M. E. Olson, D. Fraser, P. Adams, and R. C. A. THOMPSON. 2000. Prevalence and genotypic characterization of Giardia in dairy calves from Western Australia and western Canada. Veterinary Parasitology 90: 193-200.

Pavlasek, I., I. NAGL, J. Vacha, AND M. Lavicka. 1993. The first report of Giardia spp. infection in roe deer (Capreolus capreolus L.). Veterinarni Medicina 38: 381-384. [In Czech.]

Rickard, L. G., C. Siefker, C. R. Boyle, and E. J. Gentz. 1999. The prevalence of Cryptosporidium and Giardia spp. in fecal samples from free-ranging white-tailed deer (Odocoileus virginianus) in the southeastern United States. Journal of Veterinary Diagnostic Investigation 11: 65-72.

Sulaiman, I. M., R. Fayer, C. Bern, R. H. Gilman, J. M. Trout, P. M. SchantZ, P. Das, A. A. Lal, And L. XiaO. 2003. Triosephosphate isomerase gene characterization and potential zoonotic transmission of Giardia duodenalis. Emerging Infectious Disease 9: $1444-1452$

Thompson, R. C. A., R. M. Hopkins, And W. L. Homan. 2000. Nomenclature and genetic groupings of Giardia infecting mammals. Parasitology Today 16: 210-213.

van Keulan, H., P. T. Macechk, S. Wade, S. Schaaf, P. M. Wallis, And S. L. Erlandsen. 2002. Presence of human Giardia in domestic, farm, and wild animals and environmental samples suggests a zoonotic potential for giardiasis. Veterinary Parasitology 108: 97 107. 